\title{
DNA Oligonucleotide-cis-Platin Binding: Ab Initio Interpretation of the Vibrational Spectra
}

\author{
Valery Andrushchenko, ${ }^{\dagger, \ddagger}$ Hal Wieser, \\ Institute of Organic Chemistry and Biochemistry, Academy of Sciences, Flemingovo nám. 2, \\ 16610, Praha 6, Czech Republic, and Department of Chemistry, University of Calgary, \\ 2500 University Drive, Calgary AB, T2N 1N4, Canada
}

Received: June 13, 2007; In Final Form: July 13, 2007

\begin{abstract}
The cis-platin binding to the $\mathrm{d}(\mathrm{CCTGGTCC}) * \mathrm{~d}(\mathrm{GGACCAGG})$ model DNA octamer was monitored with infrared absorption (IR) and vibrational circular dichroism (VCD) spectroscopies. The spectra were modeled with the aid of density functional computations and a Cartesian coordinate-based transfer of molecular property tensors from smaller DNA fragments. Because of the fragmentation, the tensors could be calculated with a higher precision. Environmental effects, such as the presence of the solvent or the cis-platin ligand, could be included in the modeling. The solvent was modeled by an explicit inclusion of hydrogen-bound water molecules, positions of which were estimated from a molecular dynamics simulation, or by the polarized continuum COSMO model. The B3LYP and BPW91 functionals used for the calculations of the spectral parameters were combined with the relativistic LANL2DZ platinum pseudo-potentials. The simulations reproduced the main IR and VCD DNA spectral features and explained most of the changes observed experimentally upon metal binding. The results confirmed that the influence of the ligand on DNA vibrational properties is quite complex; it originates in the geometry deformation and normal mode coupling pattern changes of the platinated octamer, as well as in local perturbations of the electronic structure and force field of the GC base pairs to which the platinum is bound. Many of the local effects could be accounted for by a point charge used in place of the metal in the GC complex.
\end{abstract}

\section{Introduction}

Vibrational spectroscopy is one of the major techniques used for structural studies of biologically relevant molecules. Unlike $\mathrm{X}$-ray or NMR, it is less restricted by the size of studied systems, and the experimental conditions can be varied significantly. ${ }^{1,2}$ Moreover, vibrational optical activity techniques, such as vibrational circular dichroism (VCD) and Raman optical activity (ROA), make the structural information encoded in the spectra more apparent and add chiral and conformational sensitivity to the unpolarized techniques. ${ }^{3-6}$ Thus, more detailed information about the structure of many peptides, proteins, and nucleic acids could be deciphered in the past. ${ }^{7-11}$

However, due to the inhomogeneous broadening of vibrational bands, their overlap, and the coupling of many motions in bigger systems, it is often difficult to assign vibrational spectral features to certain transitions and structural features unambiguously. Today, the assignment process is inseparable from computer modeling and theoretical spectral simulations. The advances in computer technology and theoretical apparatuses, ${ }^{12}$ particularly density functional theory (DFT), ${ }^{13,14}$ provided the means for shedding light on the nature and origin of individual spectral bands. Particularly, the link between the vibrational spectral shape and the molecular structure could be studied more systematically. ${ }^{4,15,16}$

For nucleic acids and similar large molecular systems that cannot be directly subjected to accurate simulations, approximate computational schemes are available, such as the DeVoe

* Corresponding author. E-mail: bour@uochb.cas.cz.

$\dagger$ Academy of Sciences.

$\doteqdot$ University of Calgary. polarizability theory ${ }^{17}$ and other modifications of the coupled oscillator/dipole coupling models. ${ }^{17-22}$ However, these simulations often depend on ad hoc or empirical parameters, and their application especially for systems of an unusual structure, such as the DNA-cis-platin complexes, is not reliable. ${ }^{23}$ Therefore, combined quantum mechanic/molecular mechanics (QM/MM) schemes pursued in this study appear as the most profitable, due to their flexibility and at least the theoretical possibility of improving systematically the accuracy up to the quantum limit. ${ }^{24}$

Particularly, we attempted to explain changes in the vibrational properties of a DNA model octamer upon formation of a complex with cis-diamminedichloroplatinum(II) (cis-platin or cis-Pt). This compound is a well-known anticancer drug that binds to DNA in the living cell and thus inhibits replication. ${ }^{25,26}$ NMR studies of a metalated DNA duplex suggest that the platinum binds to the N7 site of two neighboring guanines in the GG sequence. ${ }^{27,28}$ The binding significantly perturbs the regular DNA geometry. The parallel stacking of the guanine bases is destroyed, and the double helix bends toward the major groove at the platination site. The distortions of the DNA geometry predicted by NMR studies were also detected by IR and VCD spectroscopy. ${ }^{29}$ Thus, a reliable theoretical model used as a basis for the peak assignments and explanation of the spectral alterations is needed.

$\mathrm{Ab}$ initio simulations of the VCD spectra within the harmonic approximation are relatively straightforward for rigid and small molecules. Conveniently, the magnetic field perturbation theory (MFP) of Stephens ${ }^{30,31}$ combined with DFT and field-dependent atomic orbitals ${ }^{32}$ can be applied, as implemented, for example, in the Gaussian program package. ${ }^{33}$ The size and conformational flexibility of the DNA octamer, however, hinder the direct 
modeling. The VCD signal arises mainly from the dipolar interaction between two stacked base pairs and analogous interactions of the phosphate and sugar residues. ${ }^{34,35}$ Thus, the basic unit determining the basic VCD pattern is composed of two stacked base pairs including two sugar-phosphate pairs. Modeling with suitably chosen fragments preserving these interactions can then provide enough information on the spectral response of longer nucleic acid segments. Many distinct spectral features can be assigned to localized chromophores. ${ }^{34,36}$ In addition to the computations on smaller fragments, the Cartesian tensor transfer technique ${ }^{24}$ can be used for a reproduction of the vibrational behavior of larger molecules, in the present case of the whole DNA octamer. Previously, this approach was successfully used for the simulation of IR and VCD spectra of peptides and regular DNA and RNA oligomers. ${ }^{36-40}$ In this study, we also applied it to the irregular octamer geometry, deformed by metal binding and hydration.

It is true that the density functional methods were not found to be ideal for a description of the dispersion forces and the stacking of the DNA and RNA basis. ${ }^{41}$ However, this should not affect our method of simulation of the spectra because the geometry is derived from experiment or largely empirical molecular dynamic (MD) force fields. By the normal mode method, ${ }^{42}$ the structure is not significantly changed even if it is relaxed to obtain the vibrational spectra. The stacking forces might participate in the inter-base coupling important for the spectra, but the IR and VCD pattern is predominantly determined by the dipole-dipole interactions ${ }^{21}$ reproduced by DFT correctly.

\section{Materials and Methods}

Experiment. The IR absorption and VCD spectra of free and platinated octamers were measured and published by Tsankov et al. ${ }^{29}$ previously. Therefore, we review the experimental conditions only briefly. Desalted single-stranded d(CCTGGTCC) and (GGACCAGG) complementary oligonucleotides were obtained from the University of Calgary Core DNA Services. The Pt complex preparation was achieved with a usual protocol. ${ }^{28,43}$ All solutions were prepared in a buffer containing $40 \mathrm{mM}$ cacodylate and $60 \mathrm{mM} \mathrm{NaCl}, \mathrm{pD}=6.25$. Complete deuterium exchange was achieved by lyophilizing and resolving all solutions 3 times in $\mathrm{D}_{2} \mathrm{O}$. The samples were placed between two $\mathrm{BaF}_{2}$ windows in a demountable cell (International Crystal Laboratories, Inc.) separated by a $45 \mu \mathrm{m}$ Teflon spacer. The final duplex oligonucleotide concentration in the cell was 15 $\mathrm{mM}$.

All infrared absorption and VCD spectra were measured in $\mathrm{D}_{2} \mathrm{O}$ within $800-1800 \mathrm{~cm}^{-1}$ with an instrument built at the University of Calgary. ${ }^{44}$ A total of 7500 ac scans (about $3.5 \mathrm{~h}$ scanning time) were accumulated for each sample and rationed against $500 \mathrm{dc}$ scans, all at $4 \mathrm{~cm}^{-1}$ resolution. The VCD spectra were corrected for polarization artifacts by subtracting the spectra of the solvent obtained at the same conditions.

Calculations. Four macromolecular systems were simulated: (1) the standard DNA geometry of the non-platinated octamer duplex, d(CCTGGTCC)*d(GGACCAGG), which was generated using the Biosym software (Figure 1a). ${ }^{45}$ (2) A hydrated octamer geometry including the water positions was generated with the Tinker program. ${ }^{46}$ The octamer was soaked in a $10 \AA$ water shell with $\mathrm{Na}^{+}$counterions, optimized, and subjected to 10000 steps ( $1 \mathrm{fs}$ step, $298 \mathrm{~K}$, pressure of $1 \mathrm{~atm}$ ) of MD equilibration. In the spectral simulations, only the water molecules hydrogen bonded to DNA were considered to be taken from the last instantaneous MD configuration (Figure 1b).

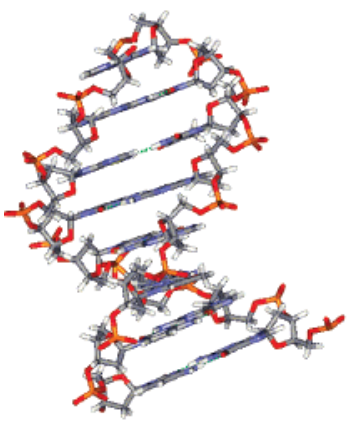

a

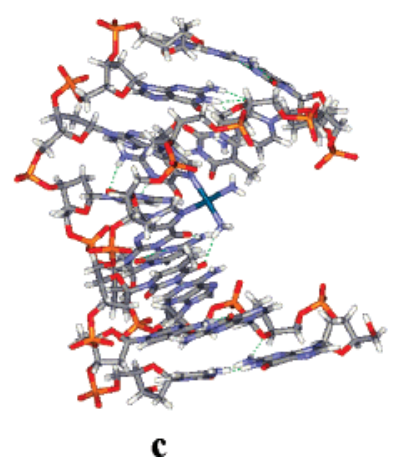

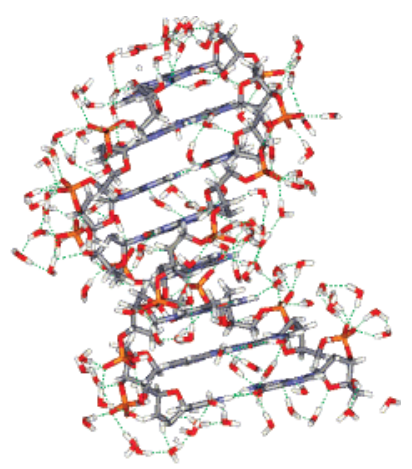

b

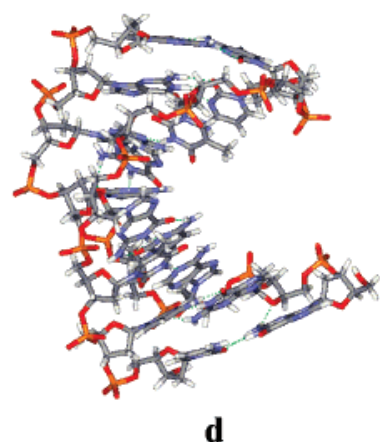

Figure 1. d(CCTGGTCC)*d(GGACCAGG) octamer geometries used in the calculations: (a) in vacuum, (b) explicitly hydrated by H-bound water molecules, (c) in the platinated complex, and (d) the distorted complex geometry without cis-Pt.

For the platinated octamer $\mathrm{d}\left(\mathrm{CCTG}^{\wedge} \mathrm{GTCC}\right) * \mathrm{~d}(\mathrm{GGACCAGG})$, the NMR geometry was used ("^" indicates the cis-Pt binding site) $)^{27}$ with (3) (Figure 1c) and without (4) (Figure 1d) the bound cis-platin.

The non-platinated octamer (1) force field was obtained from DFT computations performed on eight smaller fragments: the sugar-phosphate link and seven stacked base pairs, $\mathrm{CC} * \mathrm{GG}$, $\mathrm{CT}^{*} \mathrm{GA}, \mathrm{TG}^{*} \mathrm{AC}, \mathrm{GG}^{*} \mathrm{CC}, \mathrm{GT}^{*} \mathrm{CA}, \mathrm{TC}^{*} \mathrm{AG}$, and $\mathrm{CC} * \mathrm{GG}$ (Figure 2). All sequences are indicated in the $5^{\prime}-3^{\prime}$ direction. The irregular hydrated non-platinated octamer (2), however, had to be separated into 21 fragments including the hydrogen-bound waters. Similarly, the distorted platinated octamers (3 and 4) had to be separated into 21 fragments because the 14 sugarphosphate links could not be propagated periodically. The distorted seven base pairs can be seen in Figure 3. The MCM graphical program was used for the fragmentation. ${ }^{47}$ To distinguish the spectral changes induced by the $\mathrm{Pt}^{2+}$ ion itself from those induced solely by the octamer geometry distortion, the $\mathrm{Pt}^{2+}$ ion was removed in the octamer (4), but its geometry was preserved (Figure 1d). Similarly, the fragments involved in this modification were calculated without the $\mathrm{Pt}^{2+}$ ion.

The force field and intensity tensors ${ }^{30-32}$ of the octanucleotides were constructed from the smaller fragments using the Cartesian coordinate transfer technique. ${ }^{24} \mathrm{Ab}$ initio computations were performed with the aid of the Gaussian program. ${ }^{33}$ The geometries of the smaller fragments were partially relaxed with the aid of the normal mode optimization method. ${ }^{42,48}$ Normal modes with frequencies below $300 \mathrm{~cm}^{-1}$ were frozen, while the modes in the experimentally accessible region could relax. For the optimized fragments, harmonic force fields, dipole derivatives, and atomic axial tensors were calculated with the Gaussian program ${ }^{33}$ and transferred ${ }^{24}$ to the octamers. By default, the DFT BPW91 $49,50 / 6-31 \mathrm{G}^{* *}$ level was used because of our previous good experience with this functional providing 


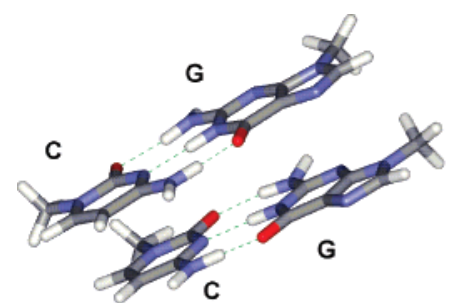

1

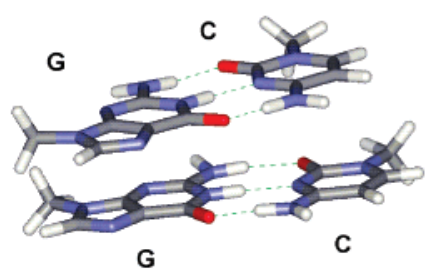

4

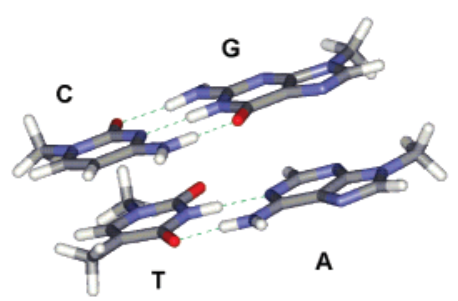

2

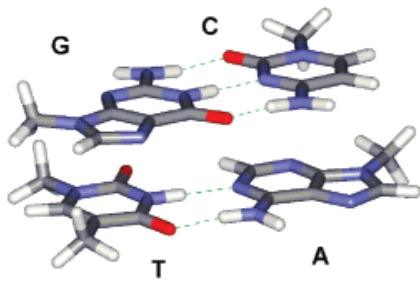

5

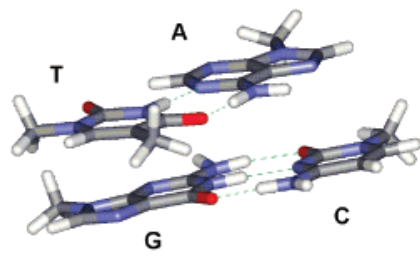

3

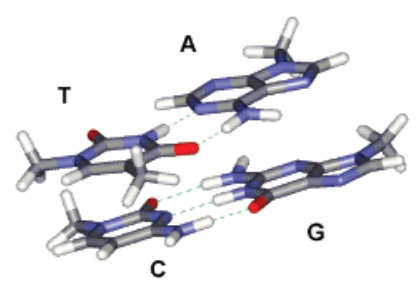

6

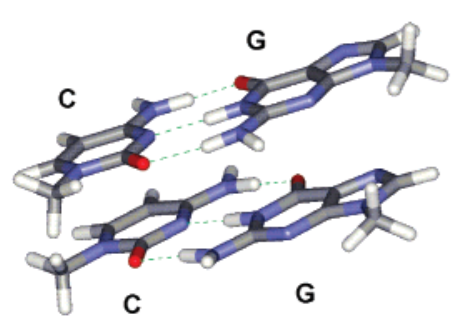

7

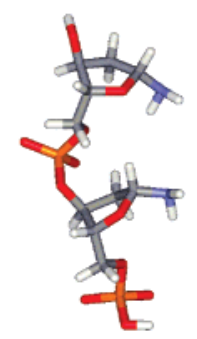

8

Figure 2. Octamer fragments used in the calculations: (1) $\mathrm{CC} * \mathrm{GG}$, (2) $\mathrm{CT} * \mathrm{GA}$, (3) $\mathrm{TG} * \mathrm{AC}$, (4) $\mathrm{GG} \mathrm{CC}$, (5) $\mathrm{GT} * \mathrm{CA}$, (6) $\mathrm{TC} * \mathrm{AG}$, and (7) CC*GG dimers and (8) the sugar-phosphate dimer.

reasonably accurate vibrational frequencies with a favorable computational cost. ${ }^{36,38,39,51}$ The LANL2DZ pseudo-potential ${ }^{52}$ and basis were used for the Pt atom. In addition to the vacuum computations, vibrational properties of smaller systems were modeled with the B3LYP 53 functional and the Gaussian version (CPCM) of the $\mathrm{COSMO}^{54}$ solvent model. The investigated systems and relevant approximations are summarized in Table 1.

Harmonic vibrational frequencies were calculated by the force field diagonalization ${ }^{55}$ for deuterated species where the acidic hydrogens (in the $\mathrm{N}-\mathrm{H}$ and $\mathrm{O}-\mathrm{H}$ groups) were replaced by deuteria. This corresponds to the experimental conditions where the heavy water is used as a solvent to avoid an interference of the $\mathrm{H}-\mathrm{O}-\mathrm{H}$ bending vibration with the DNA base modes around $1650 \mathrm{~cm}^{-1} \cdot{ }^{29}$ After an assignment of the vibrational transitions, the DNA octamer spectra were generated again with scaled fragment force fields. The scaled fields were calculated as $\mathbf{F}^{\prime}=\mathbf{S}^{t} \omega \mathbf{S}$, where the Cartesian-normal mode transformation matrix $^{55} \mathbf{S}$ was obtained with the Gaussian field, and the diagonal matrix $\omega$ contained experimentally assigned or interpolated frequencies (Tables 2 and 3). Lorentzian peaks with a full width at half-height of $5 \mathrm{~cm}^{-1}$ were used for generation of the simulated spectra from the calculated frequencies and intensities.

\section{Results and Discussion}

Platinum Binding to Guanidine and GC Pair. As can be seen in Figure 4, the metal binding significantly changes the IR spectra of the nitrogen bases in the $1500-1700 \mathrm{~cm}^{-1}$ region. The calculated spectrum of a single guanine (B3LYP/
CPCM/6-31+G**) (Figure 4, top trace) is primarily comprised of two absorption bands at $1677 \mathrm{~cm}^{-1}$ (mostly $\mathrm{C}=\mathrm{O}$ stretching) and $1573 \mathrm{~cm}^{-1}(\mathrm{C}=\mathrm{N}$ and $\mathrm{C}=\mathrm{C}$ ring stretching modes). A shoulder at $1591 \mathrm{~cm}^{-1}$ of the latter peak originates from a $\mathrm{C}=\mathrm{N}$ ring stretch. The computations are thus in agreement with the experimental assignments of the main guanine vibrations. ${ }^{56-59}$ The binding of cis-Pt to the N7 site of guanine makes the carbonyl bond slightly stronger and shifts it up to $1694 \mathrm{~cm}^{-1}$. The ring mode signal at $1591 \mathrm{~cm}^{-1}$ shifts up to $1604 \mathrm{~cm}^{-1}$ and significantly increases in intensity at the expense of the $1573 \mathrm{~cm}^{-1}$ vibration, the intensity of which decays and shifts to lower wavenumbers at $1564 \mathrm{~cm}^{-1}$. These spectral changes correspond to those observed upon complexation of guanine with other metal ions (e.g., $\left.\mathrm{Cu}^{2+}\right) .56$

The GC base pair spectrum is more complex, with a highest cytosine $\mathrm{C}=\mathrm{C}$ stretching band at $1679 \mathrm{~cm}^{-1}$, followed by the guanine $\left(1663 \mathrm{~cm}^{-1}\right)$ and cytosine $\left(1632 \mathrm{~cm}^{-1}\right)$ carbonyl stretching vibrations (Figure 4). In the spectra of the nondeuterated $\mathrm{GC}$ pair, the $\mathrm{C}=\mathrm{C}$ band downshifts below the carbonyl vibrations (data not shown). Thus, one should be careful when correlating experimental spectra of deuterated and non-deuterated samples. The band at $1591 \mathrm{~cm}^{-1}$ arises from $\mathrm{C}=\mathrm{N}$ ring vibrations of guanine, and the bands at 1575 and $1562 \mathrm{~cm}^{-1}$ arise mostly from both $\mathrm{C}=\mathrm{N}$ and $\mathrm{C}=\mathrm{C}$ ring stretching with the participation of other parts of guanine. Two lower wavenumber bands at 1547 and $1520 \mathrm{~cm}^{-1}$ originate from the $\mathrm{C}=\mathrm{N}$ and $\mathrm{C}=\mathrm{C}$ ring stretching of cytosine. These assignments are also in good agreement with the experimental data. ${ }^{57-59}$ 


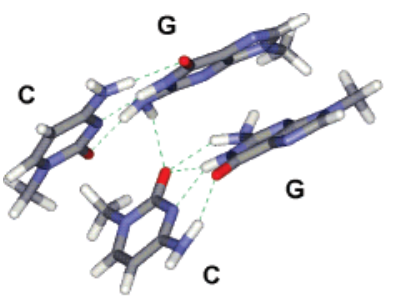

1'

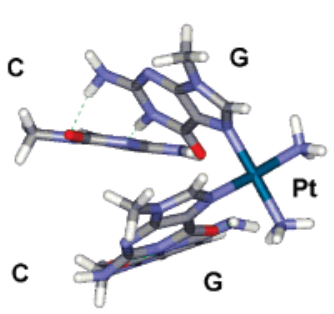

4'

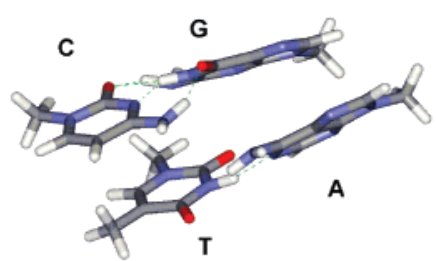

2'

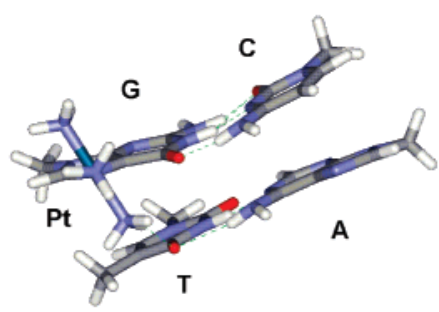

5'

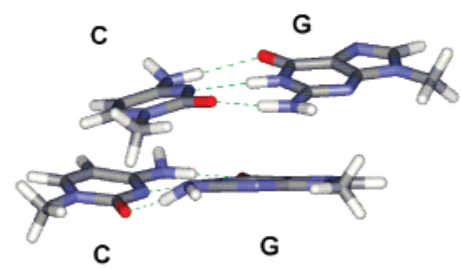

7
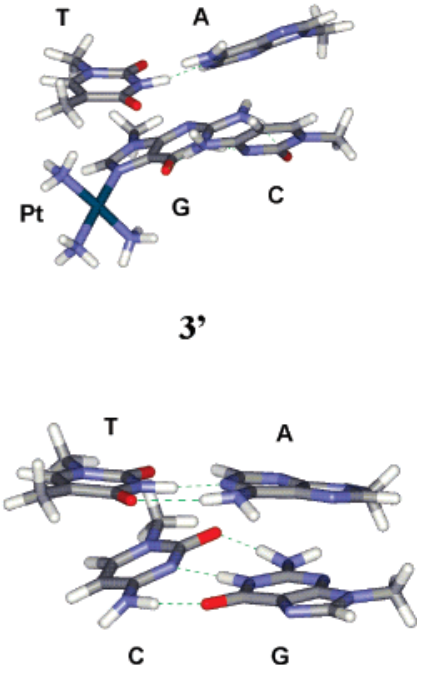

6'

Figure 3. Distorted base pair fragments from the platinated octamer: (1') CC*GG, (2') CT*GA, (3') TG-cis-Pt*AC, (4') G-cis-Pt-G*CC, (5') cis-Pt-GT*CA, (6') TC*AG, and (7') CC*GG.

TABLE 1: Fragments Used in the Computations

\begin{tabular}{|c|c|c|}
\hline system & solvent & functional and basis \\
\hline $\mathrm{G}$ & СРCM & B3LYP/6-31+G** \\
\hline $\mathrm{G}-\mathrm{Pt}$ & CPCM & B3LYP/6-31+G** \\
\hline $\mathrm{G} \cdots \mathrm{C}$ & СРCM & B3LYP/6-31+G**, BPW91/6-31+G** \\
\hline$(\mathrm{G} \cdots \mathrm{C})-\mathrm{Pt}$ & CPCM & $\mathrm{B} 3 \mathrm{LYP} / 6-31+\mathrm{G}^{* *}$ \\
\hline$(\mathrm{G} \cdots \mathrm{C})+$ charges & CPCM & B3LYP/6-31+G** \\
\hline $\begin{array}{l}\mathrm{d}(\mathrm{CCTGGTCC}) * \mathrm{~d}(\mathrm{GGACCAGG}) \text { regular fragments: } \\
\text { base pairs CC*GG,CT*GA, TG*AC, GG*CC, } \\
\text { GT*CA, TC*AG, and CC*GG; sugar-phosphate } \\
\text { dimer }\end{array}$ & vacuum & BPW91/6-31G** \\
\hline 21 irregular fragments of (CCTGGTCC)* $\mathrm{d}(\mathrm{GGACCAGG})$ & explicit $\mathrm{H}$-bound water & BPW91/6-31G** \\
\hline$(\mathrm{CCTG} \wedge \mathrm{GTCC})^{*} \mathrm{~d}(\mathrm{GGACCAGG})$ fragments: base pairs & vacuum & BPW91/6-31G** \\
\hline $\mathrm{CC} * \mathrm{GG}, \mathrm{CT} * \mathrm{GA}, \mathrm{TG}-\mathrm{Pt} * \mathrm{AC}, \mathrm{G}-\mathrm{Pt}-\mathrm{G}^{*} \mathrm{CC}, \mathrm{Pt}-$ & & \\
\hline $\mathrm{GT}^{*} \mathrm{CA}, \mathrm{TC} * \mathrm{AG}$, and $\mathrm{CC} * \mathrm{GG} ; 14$ sugar-phosphate & & \\
\hline
\end{tabular}

Upon cis-Pt binding, the carbonyl vibrations of guanine and the ring vibrations of cytosine do not change significantly, while the ring vibrations of guanine exhibit the largest modifications. Similar to the single guanine base, the relative intensities of the two bands (1591 and $1575 \mathrm{~cm}^{-1}$ ) change, as the former $\left(1587 \mathrm{~cm}^{-1}\right.$ in the $\mathrm{G} \cdots \mathrm{C}-\mathrm{Pt}$ complex) gains and the latter (1574 $\mathrm{cm}^{-1}$ ) loses intensity. Also, these changes are well-concomitant with the experimental data obtained for other metal ions, suggesting a similar influence of the metal on the vibrational properties of the guanine base. ${ }^{56}$ Interestingly, while the guanine carbonyl band displays only minor changes upon cis-Pt binding, the carbonyl band of cytosine increases in intensity and shifts substantially $\left(1632 \rightarrow 1611 \mathrm{~cm}^{-1}\right)$. The normal mode displacement of the latter vibration for the free and platinated $\mathrm{C}-\mathrm{G}$ pairs is plotted at the right side of Figure 4. It is apparent that the platinum binding causes a larger coupling of the cytosine carbonyl stretch and a guanine ring deformation. The direction of the transition dipole moment (red line in Figure 4) changes by about $20^{\circ}$. The effect of the metal-DNA complexation can thus be amplified by the hydrogen binding of the bases and a coupling of nearly degenerate vibrations.

In an attempt to estimate a purely electrostatic effect of cis$\mathrm{Pt}$ binding on the GC base pair, we replaced the $\mathrm{Pt}^{2+}$ and $\mathrm{Cl}^{-}$ ions by corresponding charges $(+2 \mathrm{e}$ and $-\mathrm{e})$ and calculated the vibrational properties without further modification of the geometry. Interestingly, the resulting spectrum (Figure 4, bottom trace) exhibits many of the spectral changes observed for the fully platinated base pair. For example, the carbonyl modes are not significantly changed, while the guanine ring mode (1582 and $1562 \mathrm{~cm}^{-1}$ ) relative intensities change in the same direction as for the metalated complex. A new $\mathrm{C}=\mathrm{C}$ stretching band of guanine appears at the highest wavenumber at $1686 \mathrm{~cm}^{-1}$. Thus, the electrostatic influence and geometry change can explain many of the spectral changes observed upon binding metal ions 
TABLE 2: Calculated (BPW91/6-31G**) and Experimental Frequencies $\left(\mathrm{cm}^{-1}\right)$ of Most Intense Spectral Bands of the d(CCTGGTCC)*d(GGACCAGG) Octamer

\begin{tabular}{|c|c|c|c|c|c|c|}
\hline \multicolumn{2}{|c|}{$\operatorname{calcd}^{a}$ (vacuum) } & \multicolumn{2}{|c|}{$\operatorname{calcd}^{a}$ (explicit water) } & \multicolumn{2}{|r|}{$\operatorname{expt}^{29}$} & \multirow[b]{2}{*}{ assignment ${ }^{b}$} \\
\hline abs & VCD & abs & VCD & abs & VCD & \\
\hline 1746 & $1746(-)$ & 1742 & $1743(-) / 1734(+)$ & 1691 & $1718(+) / 1682(-)$ & $v(\mathrm{C}=\mathrm{O} 2) \mathrm{T}$ \\
\hline 1710 & $1714(-) / 1707(+)$ & 1729,1713 & $1730(-) / 1716(+)$ & 1666 & $1671(-) / 1647(+)$ & $v(\mathrm{C}=\mathrm{O} 6) \mathrm{G}$ \\
\hline & $1688(+)$ & 1689 & $1688(+)$ & 1666 & $1671(-) / 1647(+)$ & $v(\mathrm{C}=\mathrm{O} 6) \mathrm{G}, v(\mathrm{C}=\mathrm{O} 2) \mathrm{C}$ \\
\hline 1676 & $1678(-) / 1670(+)$ & 1665 & $1663(+)$ & 1666 & $1671(-) / 1647(+)$ & $v(\mathrm{C}=\mathrm{O} 6) \mathrm{G}, v(\mathrm{C}=\mathrm{O} 2) \mathrm{C}, v(\mathrm{C}=\mathrm{O} 4) \mathrm{T}$ \\
\hline 1648 & $1649(-)$ & 1654 & $1653(-)$ & 1666 & $1671(-) / 1647(+)$ & $\begin{array}{l}v(\mathrm{C}=\mathrm{O} 2), v(\mathrm{C}=\mathrm{N}) \text { ring, } v\left(\mathrm{C}-\mathrm{ND}_{2}\right) \\
\quad \delta(\mathrm{C}-\mathrm{H}) \mathrm{C}\end{array}$ \\
\hline 1618 & $1615(-)$ & 1628 & & 1618 & & $v(\mathrm{C}=\mathrm{N})$ ring, $v\left(\mathrm{C}-\mathrm{ND}_{2}\right), \delta(\mathrm{C}-\mathrm{H}) \mathrm{A}$ \\
\hline 1577 & $1575(-) / 1567(+)$ & $\begin{array}{l}1608,1593 \\
1581\end{array}$ & $\begin{array}{l}1607(-), 1598(-) / \\
1580(+), 1580(+)\end{array}$ & 1582 & $1585(-) / 1562(+)$ & $v(\mathrm{C}=\mathrm{N}) \operatorname{ring}, \nu\left(\mathrm{C}-\mathrm{ND}_{2}\right), \delta(\mathrm{C}-\mathrm{H}) \mathrm{G}$ \\
\hline $1567 \mathrm{~s}$ & $1575(-) / 1567(+)$ & 1568 & $1566(+)$ & $1562 \mathrm{~s}$ & $1585(-) / 1562(+)$ & $\begin{array}{l}v(\mathrm{C}=\mathrm{N}) \operatorname{ring}, v\left(\mathrm{C}-\mathrm{ND}_{2}\right), \delta(\mathrm{C}-\mathrm{H}) \\
\quad \mathrm{A}, \mathrm{G}\end{array}$ \\
\hline 1541 & $1539(+)$ & 1541 & $1542(-)$ & 1531 & $1540(+) / 1525(-)$ & $v(\mathrm{C}=\mathrm{N}), v\left(\mathrm{C}-\mathrm{ND}_{2}\right), \delta(\mathrm{C}-\mathrm{H}) \mathrm{C}$ \\
\hline 1528 & $1527(-)$ & 1527 & & 1531 & $1540(+) / 1525(-)$ & $v(\mathrm{C}=\mathrm{N}), \delta(\mathrm{C}-\mathrm{H}) \mathrm{G}$ \\
\hline 1490 & $1490(+)$ & 1499 & $1506(-) / 1495(+)$ & 1502 & $1511(-) / 1494(+)$ & $v(\mathrm{C}=\mathrm{N}), \delta(\mathrm{C}-\mathrm{H}) \mathrm{C}$ \\
\hline 1121 & & & & $1104 \mathrm{~s}$ & & sugar def. \\
\hline 10901079 & $1091(-) / 1076(+)$ & 1083 & $1087(-) / 1077(+)$ & 1085 & $1089(-) / 1072(+)$ & $v\left(\mathrm{PO}_{2}^{-}\right)$, symm., sugar \\
\hline 1056 & $1059(+) / 1050(-)$ & 1063 & $1068(-) / 1055(+)$ & 1062 & & $v(\mathrm{C}-\mathrm{O}), \mathrm{O}-\mathrm{D}$ bend, sugar \\
\hline 1026 & $1030(-) / 1023(+)$ & 1018 & $1017(+)$ & 1016 & & $\mathrm{O}-\mathrm{D}$ bend, sugar \\
\hline 981 & $983(-) / 974(+)$ & 1005 & $1005(-)$ & 971 & & $\mathrm{O}-\mathrm{D}$ bend, sugar \\
\hline 941 & $941(-)$ & 929 & $939(+) / 927(-)$ & & & delocalized modes \\
\hline 910 & $912(-) / 905(+)$ & & $916(-) / 906(+)$ & & & \\
\hline 890 & $891(-)$ & 901 & $905(+) / 900(-)$ & 895 & & \\
\hline 850 & $850(-)$ & 867 & $867(-)$ & 864 & & \\
\hline
\end{tabular}

${ }^{a}$ Calculated frequencies and normal mode assignments are based on unscaled BPW91/6-31G** force field. ${ }^{b} v$ : Stretching vibration; $\delta$ : bending vibration; and s: shoulder.

TABLE 3: Calculated (BPW91/6-31G**) and Experimental Frequencies $\left(\mathrm{cm}^{-1}\right)$ of the Most Intense Spectral Bands of the Platinated d(CCTG^GTCC)*d(GGACCAGG) Octamer

\begin{tabular}{|c|c|c|c|c|}
\hline \multicolumn{2}{|c|}{ calculation } & \multicolumn{2}{|c|}{$\operatorname{exptl}^{29}$} & \multirow[b]{2}{*}{ assignment $^{a}$} \\
\hline abs & VCD & abs & VCD & \\
\hline 1735 & $1736(-)$ & 1691 & $1697(+) / 1675(-)$ & $v(\mathrm{C}=\mathrm{O} 2) \mathrm{T}, v(\mathrm{C}=\mathrm{O} 6) \mathrm{G}$ \\
\hline 1717 & $1723(-) / 1712(+)$ & 1667 & $1668(+) / 1662(-)$ & $v(\mathrm{C}=\mathrm{O} 2) \mathrm{T}, v(\mathrm{C}=\mathrm{O} 6) \mathrm{G}, v(\mathrm{C}=\mathrm{O} 2) \mathrm{C}$ \\
\hline 1686 & $1686(-)$ & 1667 & $1668(+) / 1662(-)$ & $v(\mathrm{C}=\mathrm{O} 6) \mathrm{G}, v(\mathrm{C}=\mathrm{O} 2) \mathrm{C}, v(\mathrm{C}=\mathrm{O} 4) \mathrm{T}$ \\
\hline 1670 & $1670(+)$ & 1667 & $1668(+) / 1662(-)$ & $v(\mathrm{C}=\mathrm{O} 6) \mathrm{G}, v(\mathrm{C}=\mathrm{O} 2) \mathrm{C}, v(\mathrm{C}=\mathrm{O} 4) \mathrm{T}$ \\
\hline 1650 & & 1667 & $1668(+) / 1662(-)$ & $v(\mathrm{C}=\mathrm{N})$ ring, $\delta(\mathrm{C}-\mathrm{H}) \mathrm{C}, \mathrm{T}$ \\
\hline 1630 & $1633(+) / 1627(-)$ & 1623 & $1643(+) / 1619(-)$ & $v(\mathrm{C}=\mathrm{N})$ ring, $v\left(\mathrm{C}-\mathrm{ND}_{2}\right), \delta(\mathrm{C}-\mathrm{H}) \mathrm{A}$ \\
\hline 1611 & $1611(+)$ & & & $v(\mathrm{C}=\mathrm{N}) \operatorname{ring}, v\left(\mathrm{C}-\mathrm{ND}_{2}\right), \delta(\mathrm{C}-\mathrm{H}) \mathrm{A}$ \\
\hline 1587 & $1588(+)$ & 1587 & $1599(+) / 1588(-)$ & $v(\mathrm{C}=\mathrm{N}) \operatorname{ring}, \nu\left(\mathrm{C}-\mathrm{ND}_{2}\right), \delta(\mathrm{C}-\mathrm{H}) \mathrm{G}, \mathrm{A}$ \\
\hline 1580 & $1580(-)$ & $1569 \mathrm{~s}$ & & $\begin{array}{l}\nu(\mathrm{C}=\mathrm{N}) \text { ring, } \nu\left(\mathrm{C}-\mathrm{ND}_{2}\right), \delta(\mathrm{C}-\mathrm{H}) \mathrm{G} \\
v(\mathrm{C}=\mathrm{N}) \text { ring, } \nu\left(\mathrm{C}-\mathrm{ND}_{2}\right), \delta(\mathrm{C}-\mathrm{H}) \mathrm{G}\end{array}$ \\
\hline 1551 & $1551(-)$ & & & $v(\mathrm{C}=\mathrm{N}) \operatorname{ring}, \nu\left(\mathrm{C}-\mathrm{ND}_{2}\right), \delta(\mathrm{C}-\mathrm{H}) \mathrm{G}$ \\
\hline 1525 & & 1532 & & $v(\mathrm{C}=\mathrm{N})$ ring, $v\left(\mathrm{C}-\mathrm{ND}_{2}\right), \delta(\mathrm{C}-\mathrm{H}) \mathrm{G}, \mathrm{C}$ \\
\hline 1496 & $1498(+) / 1494(-)$ & 1506 & $1510(+)$ & $v(\mathrm{C}=\mathrm{N}) \operatorname{ring}, \delta(\mathrm{C}-\mathrm{H}) \mathrm{C}$ \\
\hline 1118 & $1125(-) / 1116(+)$ & $1118 \mathrm{~s}$ & & sugar def. \\
\hline 1092 & $1091(+)$ & 1089 & $1091(-) / 1081(+)$ & $v\left(\mathrm{PO}_{2}^{-}\right)$, symm., sugar \\
\hline 1055 & $1060(-) / 1052(+)$ & & & $v(\mathrm{C}-\mathrm{O}), \mathrm{O}-\mathrm{D}$ bend, sugar \\
\hline 1042 & $1042(+)$ & $1056 \mathrm{~s}$ & $1060(+)$ & $v(\mathrm{C}-\mathrm{O}), \mathrm{O}-\mathrm{D}$ bend, sugar \\
\hline 1018 & & 1016 & & $\mathrm{O}-\mathrm{D}$ bend, sugar \\
\hline 942 & & 969 & & $\mathrm{O}-\mathrm{D}$ bend, sugar \\
\hline 915 & & 914 & & mostly sugar def. \\
\hline
\end{tabular}

${ }^{a}$ Notation is same as in Table 2 .

to DNA. For example, the spectral changes induced by cis$\mathrm{Pt}^{2+}$ in the present work resemble those obtained by $\mathrm{Cu}^{2+}$ binding. ${ }^{56}$ Although the electrostatic and electronic effects in this case are comparable, the relatively accurate modulation of the vibrational frequencies by an external electrostatic field reminds previous successes of the combined quantum-classical solvent models, where, for peptides, the solvent frequency shifts could be reproduced quantitatively. ${ }^{60-63}$

The band shape changes predicted in Figure 4 can also be reproduced with the BPW91 functional (not shown). Typically, the BPW91 method provides a uniform shift of the frequencies toward lower wavenumbers if compared to B3LYP. Similarly, the implicit CPCM water model lowers the vibrational frequencies of the polar groups if compared to a vacuum computation but does not change the normal mode ordering. We thus use the computationaly more feasible BPW91 method for simulation of the larger DNA fragments.

Changes in the DNA Fragment Spectra Caused by cisPlatin Binding. As documented in Figure 5, different fragments are differently sensitive to the metalation and exhibit different changes in IR and VCD spectra. Spectra of the fourth fragment where the platinum is bound are plotted separately in Figure 6 . The spectra of the first $\mathrm{CC}^{*} \mathrm{GG}$ (Figure 5) and fourth $\mathrm{GG}^{*} \mathrm{CC}$ (Figure 6) free fragments illustrate well various roles of the interpair coupling: the IR absorptions are almost identical, while the VCD shapes differ more notably. Also, fragments $2 \mathrm{CT}^{*} \mathrm{GA}$ and $6 \mathrm{TC} * \mathrm{AG}$ have the same base content but opposite $5^{\prime}-3^{\prime}$ base order; here, the absorptions differ more, and the VCD 


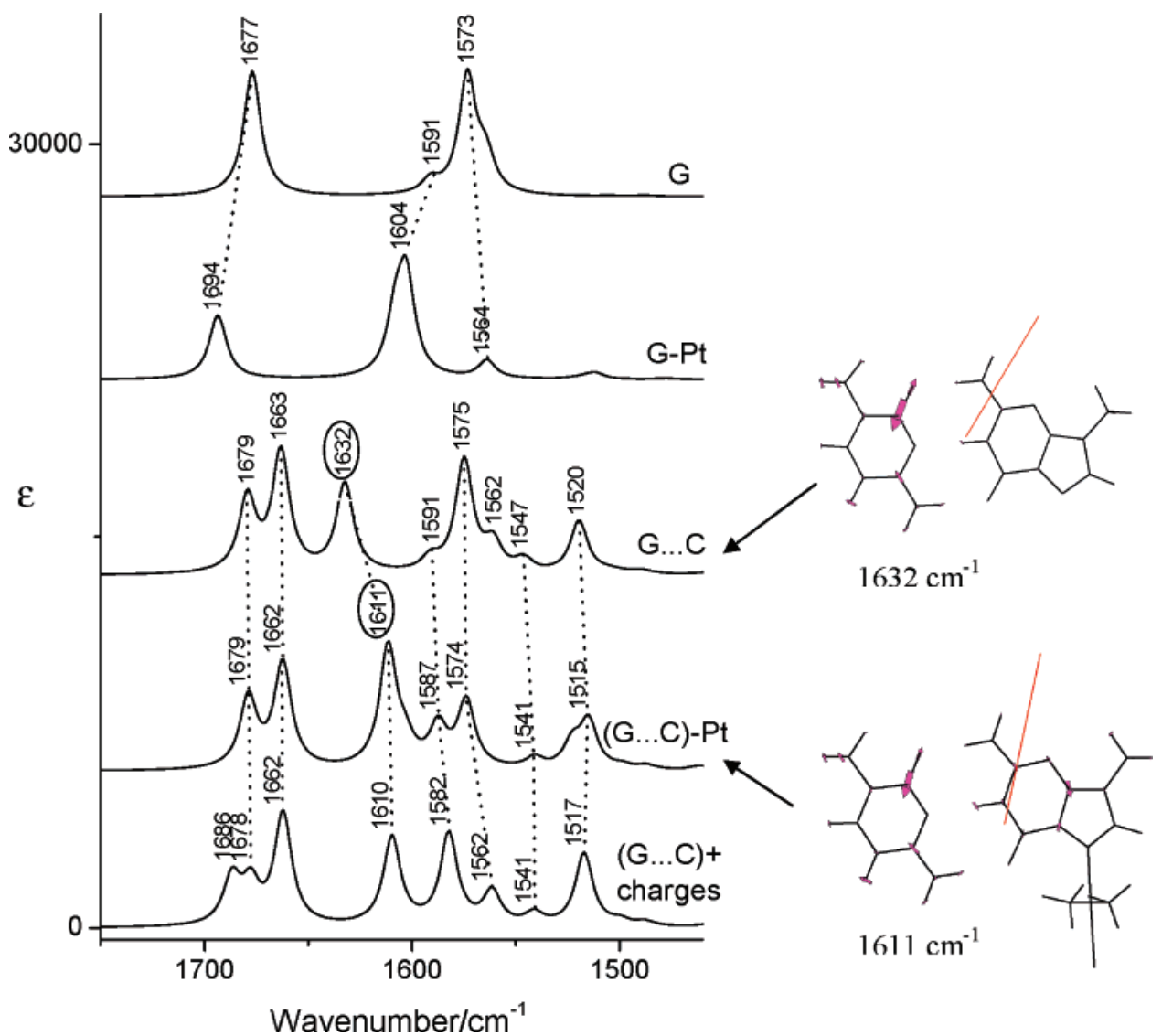

Figure 4. Comparison of IR absorption spectra of guanine $(\mathrm{G})$ and its cis-Pt complex (G-Pt), GC base pair and its cis-Pt complex ((GC)-Pt), and GC base pair with the $\mathrm{Pt}^{2+}$ and $\mathrm{Cl}^{-}$ions replaced by corresponding charges (GC + charges). The spectra were simulated at the B3LYP/CPCM/ 6-31 $+\mathrm{G}^{* *}$ level. The $\mathrm{C}=\mathrm{O} 2$ cytosine normal mode displacement for free and platinated $\mathrm{GC}$ base pairs corresponding to the absorption band with circled wavenumbers can be seen on the right side; the red lines represent the transition electric dipole moment.
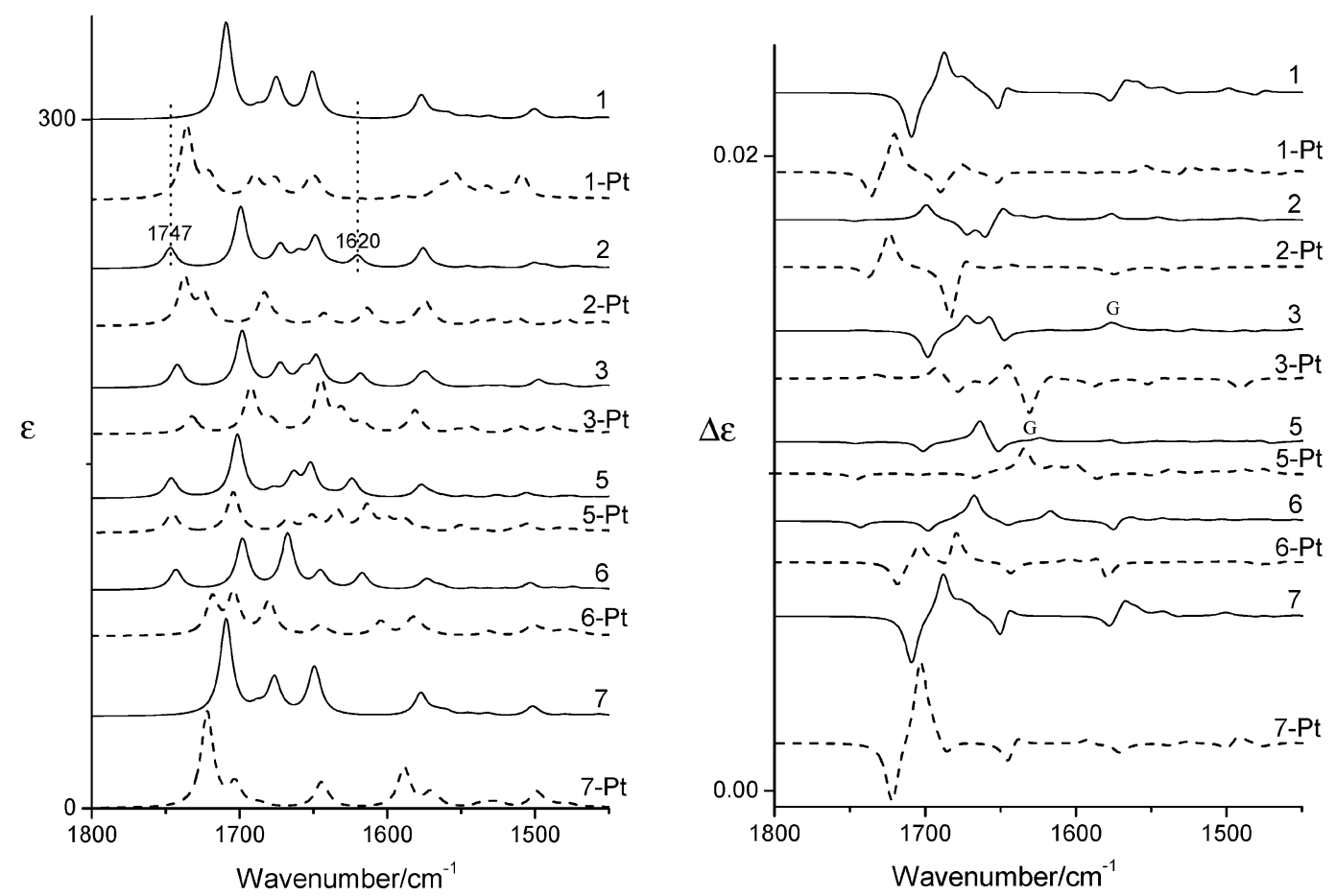

Figure 5. Calculated (BPW91/6-31G**) IR absorption (left) and VCD (right) spectra of fragments 1 (CC*GG), 2 (CT*GA), 3 (TG*AC), 5 (GT*CA), $6\left(\mathrm{TC}^{*} \mathrm{AG}\right)$, and $7(\mathrm{CC} * \mathrm{GG})$ from the non-platinated (solid line) and platinated (dashed line) octamer.

spectra even exhibit opposite signs for many bands. Coupling differences in the $3 \mathrm{TG}^{*} \mathrm{AC}$ and $5 \mathrm{GT}^{*} \mathrm{CA}$ isomers cause moderate changes both in absorption and in VCD.
Interestingly, other isomers, the $2 \mathrm{CT}^{*} \mathrm{GA}$ and $3 \mathrm{TG}^{*} \mathrm{AC}$ fragments, where the bases are permutated across the WatsonCrick pairs, provide essentially identical absorption spectra and 

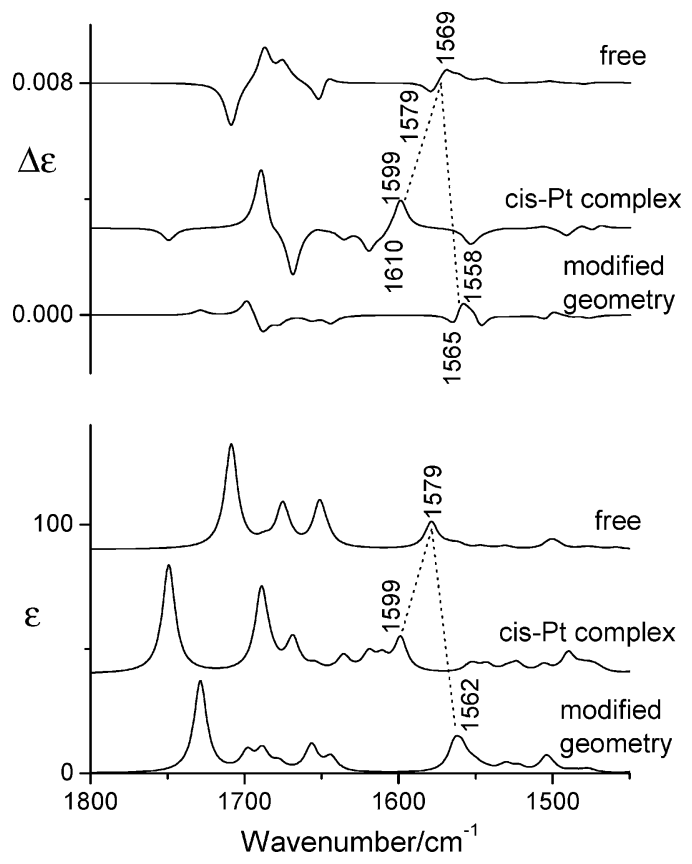

Figure 6. Calculated (BPW91/6-31G**) IR absorption $(\epsilon)$ and VCD $(\Delta \epsilon)$ spectra of fragment 4 for the free, platinated, and distorted-only octamers.

almost mirror-image VCD spectra for the carbonyl vibrations above $1630 \mathrm{~cm}^{-1}$. An analogous pair of fragments, $5 \mathrm{GT} * \mathrm{CA}$ and $6 \mathrm{TC}^{*} \mathrm{AG}$, however, provides different absorption and similar VCD.

The influence of the base composition is more predictable then that of the geometry isomerization. In comparison to the absorption of fragment $1 \mathrm{CC}^{*} \mathrm{GG}$, for example, the spectra of $2\left(\mathrm{CT}^{*} \mathrm{GA}\right)$ exhibit additional bands at $1747 \mathrm{~cm}^{-1}(\mathrm{C}=\mathrm{O} 2(\mathrm{~T}))$ and $1620 \mathrm{~cm}^{-1}$ (ring of A). These bands are present in all the other fragments containing adenine and thymine. Thus, the IR technique can, in principle, provide quantitative information about the base content in the nucleic acid sequence.

The binding of cis-Pt to the two neighboring guanines in the same strand induces significant distortion of the octamer geometry (cf. Figure 3). The base stacking is perturbed, and different coupling of the vibrations results in numerous spectral changes. For fragments 1, 2, 6, and 7 not bound to cis-Pt, all spectral changes come solely from alterations of the geometry. The alteration causes a very instructive change of the IR absorption spectra of fragments 1 and 7: the carbonyl vibrations at around $1700 \mathrm{~cm}^{-1}$ are shifted to higher wavenumbers due to the perturbation of the hydrogen-bonding pattern in the CG base pairs (Figure 5). The VCD sign pattern, however, is conserved, which corresponds to a partial preservation of the original regular octamer geometry of the terminal residues upon metal binding. An opposite change is exhibited by fragments 2 and 6 , where the highest wavenumber absorption of the $\mathrm{C}=\mathrm{O} 2(\mathrm{~T})$ group not involved in the Watson-Crick hydrogen-bonding shifts down. Absorption bands of all other carbonyls involved in hydrogen bonding are shifted to the higher wavenumbers, similar to fragments 1 and 7. Corresponding VCD bands shift accordingly (i.e., the $\mathrm{C}=\mathrm{O} 2(\mathrm{~T})$ vibrations acquire lower stretching frequencies, and $\mathrm{C}=\mathrm{O} 6(\mathrm{G}), \mathrm{C}=\mathrm{O} 4(\mathrm{~T})$, and $\mathrm{C}=\mathrm{O} 2$ (C) acquire higher stretching frequencies). Both IR and (negative) VCD intensities associated with the $\mathrm{C}=\mathrm{O} 2(\mathrm{~T})$ stretching seem to increase due to distortion.

Interestingly, the carbonyl absorption bands of fragments 3 and 5 directly chelated to cis-Pt exhibit the smallest shifts. However, the guanine ring vibrations move more toward higher
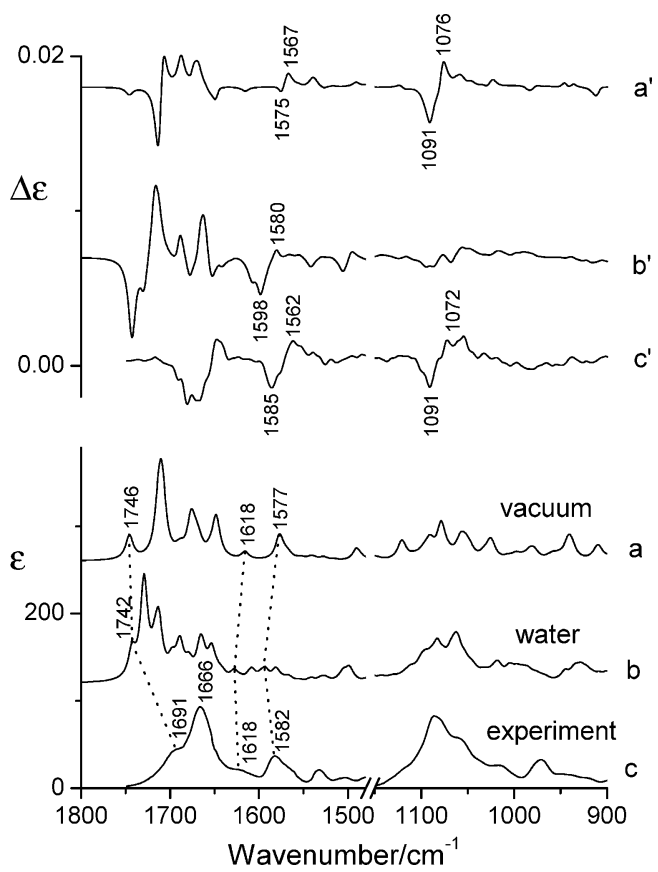

Figure 7. IR $(\epsilon)$ and $\operatorname{VCD}(\Delta \epsilon)$ of the DNA octamer spectra: comparison of the vacuum simulation (a and $a^{\prime}$ ), model with explicit water molecules ( $b$ and $b^{\prime}$ ), and experimental ${ }^{29} d($ CCTGGTCC)*d(GGACCAGG) spectra (c and $\mathrm{c}^{\prime}$ ).

wavenumbers (by up to $50 \mathrm{~cm}^{-1}$ for fragment 3 ), and the adenine ring vibrations shift down. The $\mathrm{G}$ ring absorption shift of fragment 3 (and also less extensively of fragment 5) is accompanied by a positive to negative flip and an intensity increase of the corresponding VCD band. Thus, the high sensitivity of the VCD signal to the geometry changes can be nicely documented.

Finally, in Figure 6, we investigate the changes of the spectra of fragment 4 directly bound to the $\mathrm{Pt}^{2+}$ ion. The metal ion induces significant mixing of the carbonyl and ring vibrations of $\mathrm{G}$ and $\mathrm{C}$. In the metalated fragment, these delocalized vibrations are spread between 1750 and $1600 \mathrm{~cm}^{-1}$ in both absorption and VCD. The G ring absorption at $1579 \mathrm{~cm}^{-1}$ shifts to $1599 \mathrm{~cm}^{-1}$ and is followed by a corresponding VCD couplet $\left(1579(-) / 1569(+) \rightarrow 1610(-) / 1599(+) \mathrm{cm}^{-1}\right)$, which additionally increases in intensity. Similar spectral changes of the $G$ ring vibrations have been observed experimentally upon $\mathrm{Cu}^{2+}$ binding to guanosine..$^{56}$

Spectral changes caused exclusively by the DNA geometry change can also be seen in Figure 6 on the simulated IR and VCD spectra of the distorted fragment 4 without metal. The spectral alterations are less extensive than in the presence of bound platinum cation. The $\mathrm{G}$ ring mode of the free fragment $\left(1579 \mathrm{~cm}^{-1}\right)$ actually shifts to the opposite direction under the distortion $\left(1562 \mathrm{~cm}^{-1}\right)$, and its weak VCD couplet changes to a W-shaped signal. In the higher frequency region $(>1600$ $\mathrm{cm}^{-1}$ ), however, the geometry modification significantly contributes to the total spectral changes under the full metalation. Interestingly, the modified geometry VCD couplet at $\sim 1700$ $\mathrm{cm}^{-1}$ conserves sign but becomes much stronger when the platinum is actually bound. The coupling between the carbonyl vibrations is thus significantly destroyed by geometrical modifications. The VCD intensity decreases and is enhanced again by the presence of the metal ion.

Octamer Vibrations and Experimental Peak Assignments. First, in Figure 7, we can estimate the effect of the first hydration shell on the spectra. The wavenumber region of about 1150- 

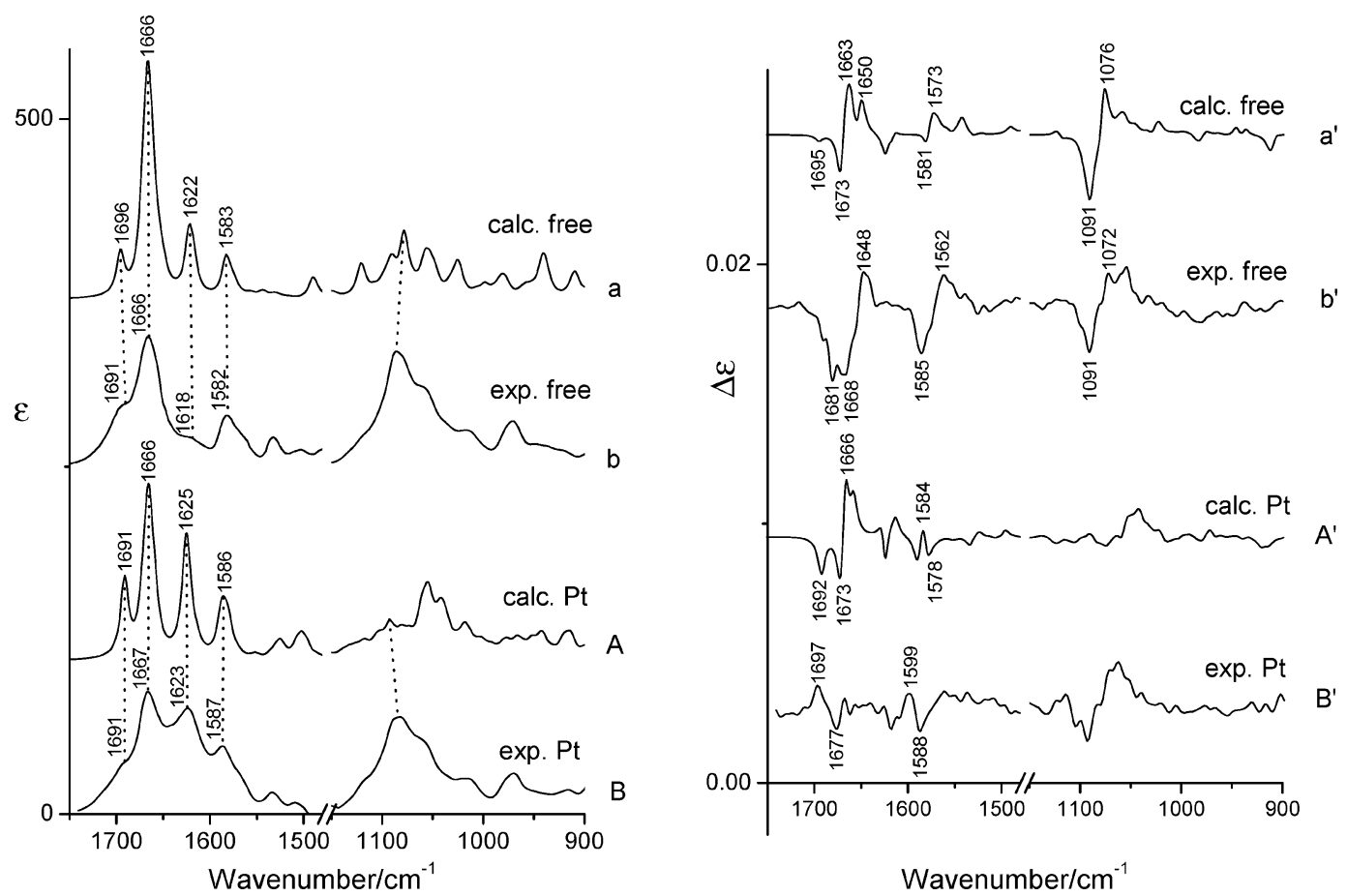

Figure 8. Calculated (a and $\mathrm{a}^{\prime}$ and $\mathrm{A}$ and $\mathrm{A}^{\prime}$, with the scaled BPW91/6-31G** fragment force field) and experimental ${ }^{29}\left(\mathrm{~b}\right.$ and $\mathrm{b}^{\prime}$ and $\mathrm{B}$ and $\mathrm{B}^{\prime}$ ) IR absorption (left) and VCD (right) spectra of the free ( $a$ and $a^{\prime}$ and $b$ and $b^{\prime}$ ) and platinated (A and $A^{\prime}$ and $\mathrm{B}^{\prime}$ and $\left.\mathrm{B}^{\prime}\right)$ octamers.

$1450 \mathrm{~cm}^{-1}$ is not plotted because of the interference of the $\mathrm{D}_{2} \mathrm{O}$ absorption. Otherwise, in the experimental spectra (traces $\mathrm{c}$ and $c^{\prime}$ in Figure 7), we can distinguish the sugar-phosphate (900$1150 \mathrm{~cm}^{-1}$ ) signal and the higher frequency $1450-1800 \mathrm{~cm}^{-1}$ region dominated by the vibrations of the bases. Typically, the $\mathrm{C}=\mathrm{O}$ stretching contributes most to the strongest IR signal within $\sim 1650-1750 \mathrm{~cm}^{-1} \cdot 29,36,39,40$

The carbonyl vibrations are also the most sensitive to the hydration. For an isolated carbonyl group or in peptidic systems, the hydrogen binding to water molecules shifts down the $\mathrm{C}=\mathrm{O}$ stretching vibration by tens of centimeters ${ }^{-1} \cdot{ }^{60,61,64}$ However, the DNA geometry significantly prevents access of the solvent to the base carbonyl groups. ${ }^{39,40}$ Moreover, the Watson-Crick hydrogen bonds are as strong as those to the solvent and thus comparably affect the carbonyl vibrations. Thus, the aqueous environment $\left(\mathrm{D}_{2} \mathrm{O}\right)$ causes mostly a redistribution of vibrational mode intensities but only minor frequency changes. For example, the highest energy absorption band in the calculated spectra (assigned to $\mathrm{C}=\mathrm{O} 2 \mathrm{~T}$ (Table 2)) is shifted from 1746 to $1742 \mathrm{~cm}^{-1}$, and the corresponding negative VCD band gains intensity.

The other carbonyl bands $(\mathrm{C}=\mathrm{O} 6$ of $\mathrm{G}, \mathrm{C}=\mathrm{O} 2$ of $\mathrm{C}$, and $\mathrm{C}=\mathrm{O} 4$ of $\mathrm{T}$; see Table 2 for detailed assignments) are widespread in both vacuum $\left(1710-1648 \mathrm{~cm}^{-1}\right)$ and water (1729-1654 $\mathrm{cm}^{-1}$ ) calculations. The calculated wavenumber span appears overestimated if compared to the width of the experimental signal centered at $1666 \mathrm{~cm}^{-1}$. The three carbonyls thus appear to be in a very similar environment and vibrate at a similar frequency. The inclusion of the hydration layer in the modeling reproduces the intensity built up in a narrower range only partially. Presumably, other factors currently inaccessible by the modeling, such as the dynamics and structural fluctuations, must be taken into account for a better model. In any case, the experimental peak overlap hinders a band-to-band comparison. The VCD signal is somewhat more resolved with respect to individual vibrations, and the basic sign pattern is reproduced both by the vacuum and by the hydrated model; however, a detailed structure explanation is still incomplete. The difficulty to reproduce the fine splitting of the carbonyl vibrations was observed also in previous attempts to simulate the DNA and RNA spectra on the basis of quantum chemical methods. ${ }^{39,40}$

On the other hand, other vibrations approximately below 1630 $\mathrm{cm}^{-1}$ are resolved more and can be assigned more clearly; for example, in the adenine ring deformation $\left(1618 \mathrm{~cm}^{-1}\right)$, where the experimental wavenumber is reproduced very accurately by the simulation or the guanine ring mode (simulated at 1577 , observed at $1582 \mathrm{~cm}^{-1}$ ). The effect of hydration on these modes is relatively minor due to experimentally low accessibility by water molecules, and a systematic improvement cannot be observed for frequencies or for intensities. For the sugarphosphate backbone fairly accessible by solvent, the water almost destroys the vacuum VCD couplet around $1090 \mathrm{~cm}^{-1}$, also visible in the experiment, but the absorption profile in this region is improved after hydration. The present work also simulates the spectra in the $900-1150 \mathrm{~cm}^{-1}$ region much more faithfully than previous studies ${ }^{36}$ that did not use the normal mode optimization technique. ${ }^{42,48}$ We explain this by the good relaxation of the shallow potential vibrations of the sugarphosphate backbone that can be achieved by normal modes. In the older approach, torsion angle constraints used to mimic the desired DNA geometry prevented the higher frequency normal mode relaxation, and the IR and VCD spectra were less realistic.

Because of the accuracy limitations of the calculated frequencies, we scaled the fragment force fields according to the normal mode assignments detailed in Tables 2 and 3 and used the field in the tensor transfer and construction of the octamer normal mode vibrations. The IR and VCD spectra simulated in this way are compared to the experiment for the free and platinated octamers in Figure 8. Clearly, although the scaling does not lead to a perfect agreement, it makes the visual comparison much easier (cf. Figure 7). Moreover, spectral changes caused by complexation are more apparent. For example, for the experimental absorption spectra (left side in Figure 8), the metalation causes an intensity increase of the $1618 \mathrm{~cm}^{-1}$ adenine ring peak in the free octamer, and its wavenumber shifts to 1623 
$\mathrm{cm}^{-1}$. This can be reproduced as the calculated signal at 1622 $\mathrm{cm}^{-1}$ of the free octamer changes to a more intense $1625 \mathrm{~cm}^{-1}$ band of the platinated one. Also, the intensity increase and the modest high-wavenumber shift of the guanine ring absorption (experimental $1582 \rightarrow 1587$, calculated $1583 \rightarrow 1586 \mathrm{~cm}^{-1}$ ) are captured by the modeling. Previously, the intensity increase of the adenine band was explained by a more intense interaction of two adenine bases in the sequence caused by a significant distortion of the octamer upon platination. ${ }^{29}$ However, similar alterations of the adenine ring absorptions were also observed upon breaking of the hydrogen bonds with a complementary base. ${ }^{65,66}$ The spectral changes of the guanine ring band upon the platination obtained from the model calculations for a single guanine base and a single GC base pair and are in agreement with the previous assignments. ${ }^{56}$

Other absorption intensities do not change much in experiment nor in simulation, or the change might be obscured by a band overlap. A very minor change in the sugar-phosphate vibration region $\left(900-1150 \mathrm{~cm}^{-1}\right)$ suggests that this part of the DNA molecule participates in the cis-Pt binding rather indirectly, which is in agreement with other studies.

The VCD changes are more complex. Experimentally, a negative signal at $1681 \mathrm{~cm}^{-1}$ of the free octamer shifts to 1677 $\mathrm{cm}^{-1}$, and a new positive band at $1697 \mathrm{~cm}^{-1}$ appears. These variations in the carbonyl VCD signal are not reproduced adequately by our model. However, the experimental flip of the guanine VCD couplet at $1585(-) / 1562(+)$ to $1599(+) / 1588$ $(-) \mathrm{cm}^{-1}$ is reproduced by the simulations much more accurately $(1581(-) / 1573(+)$ changes to $1584(+) / 1578(-))$. We attribute the worst performance of the VCD simulations for the carbonyl vibrations and the better agreement for the ring modes to a higher polarity of the carbonyls and also to their volatility to dynamical effects, currently inaccessible to high-precision quantum simulations. Additionally, the experimental geometry obtained with the aid of NMR parameters ${ }^{27}$ might not be perfect for the simulations of the VCD spectra so sensitive to molecular conformation.

\section{Conclusion}

The combination of the ab initio (DFT) computation of the spectral parameters with the Cartesian tensor transfer techniques enabled us to assign all the observable spectral features to DNA vibrations and to validate the previously proposed platinum binding site (N7 of $\mathrm{G}$ ). The simulated changes in the IR and VCD spectra are consistent with the NMR proposition of the DNA - cis-Pt adduct geometry, except for the detailed carbonyl VCD pattern. The significant modification in the IR and VCD spectra observed experimentally ${ }^{29}$ could be readily attributed to the complex formation. Major changes characteristic for the complexation are visible in the higher frequency region (1500$\left.1700 \mathrm{~cm}^{-1}\right)$. Particularly, the high wavenumber shifts and intensity increases of the adenine and guanine ring absorption bands were reproduced by the modeling. The analytically important guanine band shift stems from an electron density redistribution induced by the metal ion and is not dependent on nonlocal DNA geometrical distortions. This confirms previous suggestions based on the experimental studies. Inclusion of the explicit hydration shell around the octamer slightly improved the computed frequencies; however, it could not account for all discrepancies and occasionally even introduced new ones. Therefore, scaling of the vacuum force fields appeared to be a better instrument for improvement of the agreement with the experiment and assignment of the vibrations.
Acknowledgment. This work was supported by the Grant Agency of the Academy of Sciences (A4055104) and the Grant Agency of the Czech Republic (203/01/0031) (P.B.), a Grant from the Natural Sciences and Engineering Research Council of Canada (H.W.), and a Postdoctoral Fellowship from the Alberta Heritage Foundation for Medical Research (V.A.). We thank D. Tsankov for providing absorption and VCD spectra of the octamers.

\section{References and Notes}

(1) Mantsch, H. H.; Chapman, D. Infrared Spectroscopy of Biomolecules; Wiley-Liss: Chichester, U.K., 1996.

(2) Williams, R. W.; Dunker, A. K. J. Mol. Biol. 1981, 152, 783.

(3) Keiderling, T. A. Peptide and protein conformational studies with vibrational circular dichroism and related spectroscopies. In Circular Dichroism: Principles and Applications, 2nd ed.; Berova, N., Nakanishi, K., Woody, R. W., Eds.; Wiley-VCH: New York, 2000; p 621.

(4) Keiderling, T. A. Curr. Opin. Chem. Biol. 2002, 6, 682.

(5) Barron, L. D.; Zhu, F.; Hecht, L. Vib. Spectrosc. 2006, 42, 15.

(6) Barron, L. D.; Hecht, L.; McColl, I. H.; Blanch, E. W. Mol. Phys. 2004, 102, 731 .

(7) Keiderling, T. A. Vibrational circular dichroism. Applications to conformational analysis of biomolecules. In Circular Dichroism and the Conformational Analysis of Biomolecules; Fasman, G. D., Ed.; Plenum Press: New York, 1996; p 555. 727.

(8) Polavarapu, P. L.; Zhao, C. Fresenius' J. Anal. Chem. 2000, 366,

(9) Diem, M. Introduction to Modern Vibrational Spectroscopy; J. Wiley and Sons: New York, 1993.

(10) Nafie, L. A. Biologically relevant applications of vibrational circular dichroism. In Spectroscopy in the Biomedical Sciences; Gendreau, R. N., Ed.; CRC Press: Boca Raton, FL, 1986; p 141.

(11) Andrushchenko, V.; Tsankov, D.; Wieser, H. J. Mol. Struct. 2003, $661,541$.

(12) The Encyclopedia of Computational Chemistry; Schleyer, P. R., Allinger, N. L., Clark, T., Gasteiger, J., Kollman, P. A., Schaefer, H. F., III, Schreiner, P. R., Eds.; John Wiley and Sons: New York, 1998.

(13) Parr, R. G.; Yang, W. Density-Functional Theory of Atoms and Molecules; Oxford University Press: New York, 1994.

(14) Sponer, J.; Hobza, P. Collect. Czech. Chem. Commun. 2003, 68, 2231.

(15) Bouř, P.; Keiderling, T. A. J. Am. Chem. Soc. 1993, 115, 9602.

(16) Rauk, A. Vibrational circular dichroism intensities: Ab initio calculations. In New Developments in Molecular Chirality; Mezey, P. G., Ed.; Kluwer Academic Publishers: Dordrecht, The Netherlands, 1991; $\mathrm{p}$ 57.

(17) Devoe, H. J. Phys. Chem. 1971, 75, 1509

(18) Holzwarth, G.; Chabay, I. J. Chem. Phys. 1972, 57, 1632.

(19) Tinoco, I. Radiat. Res. 1963, 20, 133.

(20) Bouř, P.; Keiderling, T. A. J. Am. Chem. Soc. 1992, 114, 9100.

(21) Maharaj, V.; Rauk, A.; van de Sande, J. H.; Wieser, H. J. Mol. Struct. 1997, 408, 315 .

(22) Self, B. D.; Moore, D. S. Biophys. J. 1998, 74, 2249

(23) Annamalai, A.; Keiderling, T. A.; Chickos, J. S. J. Am. Chem. Soc. 1984, 106, 6254

(24) Bouř, P.; Sopková, J.; Bednárová, L.; Maloň, P.; Keiderling, T. A. J. Comput. Chem. 1997, 18, 646.

(25) Cohen, S. M.; Lippard, S. J. Prog. Nucleic Acid Res. Mol. Biol. 2001, 67, 93 .

(26) Reedijk, J. Pure Appl. Chem. 1987, 59, 181.

(27) Yang, D. Z.; Vanboom, S. S. G. E.; Reedijk, J.; Vanboom, J. H.; Wang, A. H. J. Biochemistry 1995, 34, 12912.

(28) Gelasco, A.; Lippard, S. J. Biochemistry 1998, 37, 9230.

(29) Tsankov, D.; Kalisch, B.; van de Sande, H. J.; Wieser, H. J. Phys. Chem. B 2003, 107, 6479.

(30) Stephens, P. J. J. Phys. Chem. 1985, 89, 748.

(31) Stephens, P. J. J. Phys. Chem. 1987, 91, 1712.

(32) Cheeseman, J. R.; Frisch, M. J.; Devlin, F. J.; Stephens, P. J. Chem. Phys. Lett. 1996, 252, 211.

(33) Frisch, M. J.; Trucks, G. W.; Schlegel, H. B.; Scuseria, G. E.; Robb, M. A.; Cheeseman, J. R.; Montgomery, J. A., Jr.; Vreven, T.; Kudin, K. N.; Burant, J. C.; Millam, J. M.; Iyengar, S. S.; Tomasi, J.; Barone, V.; Mennucci, B.; Cossi, M.; Scalmani, G.; Rega, N.; Petersson, G. A.; Nakatsuji, H.; Hada, M.; Ehara, M.; Toyota, K.; Fukuda, R.; Hasegawa, J.; Ishida, M.; Nakajima, T.; Honda, Y.; Kitao, O.; Nakai, H.; Klene, M.; Li, X.; Knox, J. E.; Hratchian, H. P.; Cross, J. B.; Bakken, V.; Adamo, C.; Jaramillo, J.; Gomperts, R.; Stratmann, R. E.; Yazyev, O.; Austin, A. J.; Cammi, R.; Pomelli, C.; Ochterski, J. W.; Ayala, P. Y.; Morokuma, K.; Voth, G. A.; Salvador, P.; Dannenberg, J. J.; Zakrzewski, V. G.; Dapprich, S.; Daniels, A. D.; Strain, M. C.; Farkas, O.; Malick, D. K.; Rabuck, A. 
D.; Raghavachari, K.; Foresman, J. B.; Ortiz, J. V.; Cui, Q.; Baboul, A. G.; Clifford, S.; Cioslowski, J.; Stefanov, B. B.; Liu, G.; Liashenko, A.; Piskorz, P.; Komaromi, I.; Martin, R. L.; Fox, D. J.; Keith, T.; Al-Laham, M. A.; Peng, C. Y.; Nanayakkara, A.; Challacombe, M.; Gill, P. M. W.; Johnson, B.; Chen, W.; Wong, M. W.; Gonzalez, C.; Pople, J. A. Gaussian 03, revision C.02; Gaussian, Inc.: Pittsburgh, PA, 2004.

(34) Birke, S. S.; Diem, M. Biophys. J. 1995, 68, 1045.

(35) Zhong, W. X.; Gulotta, M.; Goss, D. J.; Diem, M. Biochemistry 1990, 29, 7485 .

(36) Andrushchenko, V.; Wieser, H.; Bouř, P. J. Phys. Chem. B 2002 106,12623

(37) Bouř, P.; Kubelka, J.; Keiderling, T. A. Biopolymers 2002, 65, 45.

(38) Bouř, P.; Kubelka, J.; Keiderling, T. A. Biopolymers 2000, 53, 380

(39) Andrushchenko, V.; Wieser, H.; Bouř, P. J. Phys. Chem. B 2004, 108,3899

(40) Bouř, P.; Andrushchenko, V.; Kabelac, M.; Maharaj, V.; Wieser, H. J. Phys. Chem. B 2005, 109, 20579

(41) Cerný, J.; Hobza, P. Phys. Chem. Chem. Phys. 2005, 7, 1624.

(42) Bouř, P.; Keiderling, T. A. J. Chem. Phys. 2002, 117, 4126.

(43) Tsankov, D.; Kalisch, B.; van de Sande, J. H.; Wieser, H. Biopolymers 2003, 72, 490 .

(44) Tsankov, D.; Eggimann, T.; Wieser, H. Appl. Spectrosc. 1995, 49, 32.

(45) Insight II; Accelrys, Inc.: San Diego, 1995

(46) Ponder, J. W. Tinker, Software Tools for Molecular Design, 3.8 ed.; Washington University School of Medicine: Saint Louis, 2000.

(47) Bouř, P.; Maloň, P. MCM Molecular Graphics; Academy of Sciences: Prague, 1995-2005.

(48) Bouř, P. Collect. Czech. Chem. Commun. 2005, 70, 1315.
(49) Becke, A. D. J. Chem. Phys. 1993, 98, 5648.

(50) Perdew, J. P.; Wang, Y. Phys. Rev. B 1992, 45, 13244.

(51) Bouř, P.; McCann, J.; Wieser, H. J. Phys. Chem. A 1998, 102, 102.

(52) Hay, P. J.; Wadt, W. R. J. Chem. Phys. 1985, 82, 299.

(53) Becke, A. D. J. Chem. Phys. 1993, 98, 1372.

(54) Klamt, A.; Jonas, V.; Burger, T.; Lohrentz, J. C. W. J. Phys. Chem. A 1998, 102, 5074 .

(55) Papoušek, D.; Aliev, M. R. Molecular Vibrational/Rotational Spectra; Academia: Prague, 1982.

(56) Fritzsche, H.; Zimmer, C. Eur. J. Biochem. 1968, 5, 42.

(57) Tsuboi, M. Appl. Spectrosc. Rev. 1969, 3, 45.

(58) Tsuboi, M. Infrared and Raman spectroscopy. In Basic Principles in Nucleic Acid Chemistry; Ts'o, P. O. P., Ed.; Academic Press: New York, 1974; Vol. 1, p 399.

(59) Tsuboi, M.; Takahashi, S.; Harada, I. Infrared and Raman spectra of nucleic acids: Vibrations in the base-residues. In Physicochemical Properties of Nucleic Acids; Academic Press: London, 1973; Vol. 2, p 91.

(60) Bouř, P.; Michalík, D.; Kapitán, J. J. Chem. Phys. 2005, 122, 144501 .

(61) Bouř, P. J. Chem. Phys. 2004, 121, 7545

(62) Lee, K. K.; Hahn, S.; Oh, K. I.; Choi, J. S.; Joo, C.; Lee, H.; Han, H.; Cho, M. J. Phys. Chem. B 2006, 110, 18834.

(63) Choi, J. H.; Cho, M. J. Chem. Phys. 2004, 120, 4383.

(64) Kubelka, J.; Keiderling, T. A. J. Phys. Chem. A 2001, 105, 10922.

(65) Ohms, J.; Ackermann, T. Biochemistry 1990, 29, 5237.

(66) Andrushchenko, V.; Blagoi, Y.; van de Sande, J. H.; Wieser, H. J. Biomol. Struct. Dyn. 2002, 19, 889. 